\title{
Une saline pyrénéenne
}

\section{Oriol Beltran Costa}

\section{(2) OpenEdition}

Journals

Édition électronique

URL : https://journals.openedition.org/tc/742

DOI : $10.4000 /$ tc. 742

ISSN : 1952-420X

\section{Éditeur}

Éditions de l'EHESS

\section{Édition imprimée}

Date de publication : 1 septembre 1991

ISSN : 0248-6016

\section{Référence électronique}

Oriol Beltran Costa, « Une saline pyrénéenne », Techniques \& Culture [En ligne], 15 | 1991, mis en ligne le 12 janvier 2006, consulté le 29 septembre 2022. URL : http://journals.openedition.org/tc/742 ; DOI https://doi.org/10.4000/tc.742

Ce document a été généré automatiquement le 29 septembre 2022.

Tous droits réservés 


\section{Une saline pyrénéenne}

Oriol Beltran Costa 